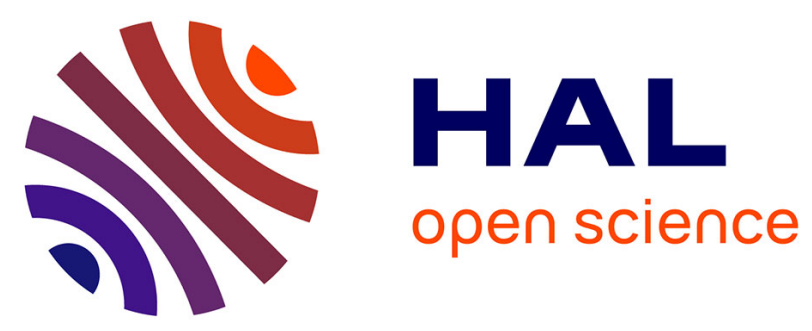

\title{
Reduction of pesticide use can increase earthworm populations in wheat crops in a European temperate region
}

Céline Pélosi, Lucile Toutous, François Chiron, Florence Dubs, Mickael Hedde, Audrey Muratet, Jean-François Ponge, Sandrine Salmon, David Makowski

\section{To cite this version:}

Céline Pélosi, Lucile Toutous, François Chiron, Florence Dubs, Mickael Hedde, et al.. Reduction of pesticide use can increase earthworm populations in wheat crops in a European temperate region. Agriculture, Ecosystems and Environment, 2013, 181, pp.223-230. 10.1016/j.agee.2013.10.003 . hal00904152

\section{HAL Id: hal-00904152 \\ https://hal.science/hal-00904152}

Submitted on 13 Nov 2013

HAL is a multi-disciplinary open access archive for the deposit and dissemination of scientific research documents, whether they are published or not. The documents may come from teaching and research institutions in France or abroad, or from public or private research centers.
L'archive ouverte pluridisciplinaire HAL, est destinée au dépôt et à la diffusion de documents scientifiques de niveau recherche, publiés ou non, émanant des établissements d'enseignement et de recherche français ou étrangers, des laboratoires publics ou privés. 
1 Reduction of pesticide use can increase earthworm populations in wheat crops in a European

2 temperate region

3

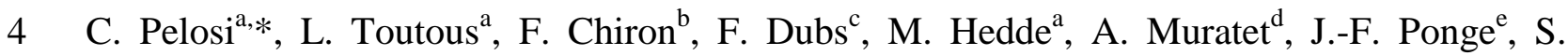
5 Salmon $^{\mathrm{e}}, \mathrm{D}$. Makowski ${ }^{\mathrm{f}, \mathrm{g}}$

6

$7 \quad{ }^{a}$ INRA, UR251 PESSAC, F-78026 Versailles cedex, France

8 b Museum national d'Histoire naturelle, UMR 7204 MNHN-CNRS-UPMC. 55 rue Buffon, 975005 Paris, France

$10{ }^{\mathrm{c}}$ IRD, UMR BIOEMCO, Centre France Nord, 93143 Bondy Cedex, France

$11{ }^{\mathrm{d}}$ ODBU, Observatoire départemental de la Biodiversité urbaine, Direction de la Nature, des 12 Paysages et de la Biodiversité, Conseil général de la Seine-Saint-Denis, Hôtel du 13 Département, F-93006 Bobigny Cedex, France

14 e Muséum National d'Histoire Naturelle, CNRS UMR 7179, 4 Avenue du Petit-Château, 1591800 Brunoy, France

$16{ }^{\mathrm{f}}$ INRA, UMR211 Agronomie, BP 01, F-78850 Thiverval-Grignon, France

$17{ }^{\mathrm{g}}$ AgroParisTech, UMR211 Agronomie, BP 01, F-78850 Thiverval-Grignon, France

$19 *$ Corresponding author: UR 251 PESSAC INRA, Bâtiment 6, RD 10, 78026 Versailles 20 cedex, France. Tel: (+33)1.30.83.36.07; Fax: (+33)1.30.83.32.59. E-mail address: $21 \quad$ celine.pelosi@versailles.inra.fr 


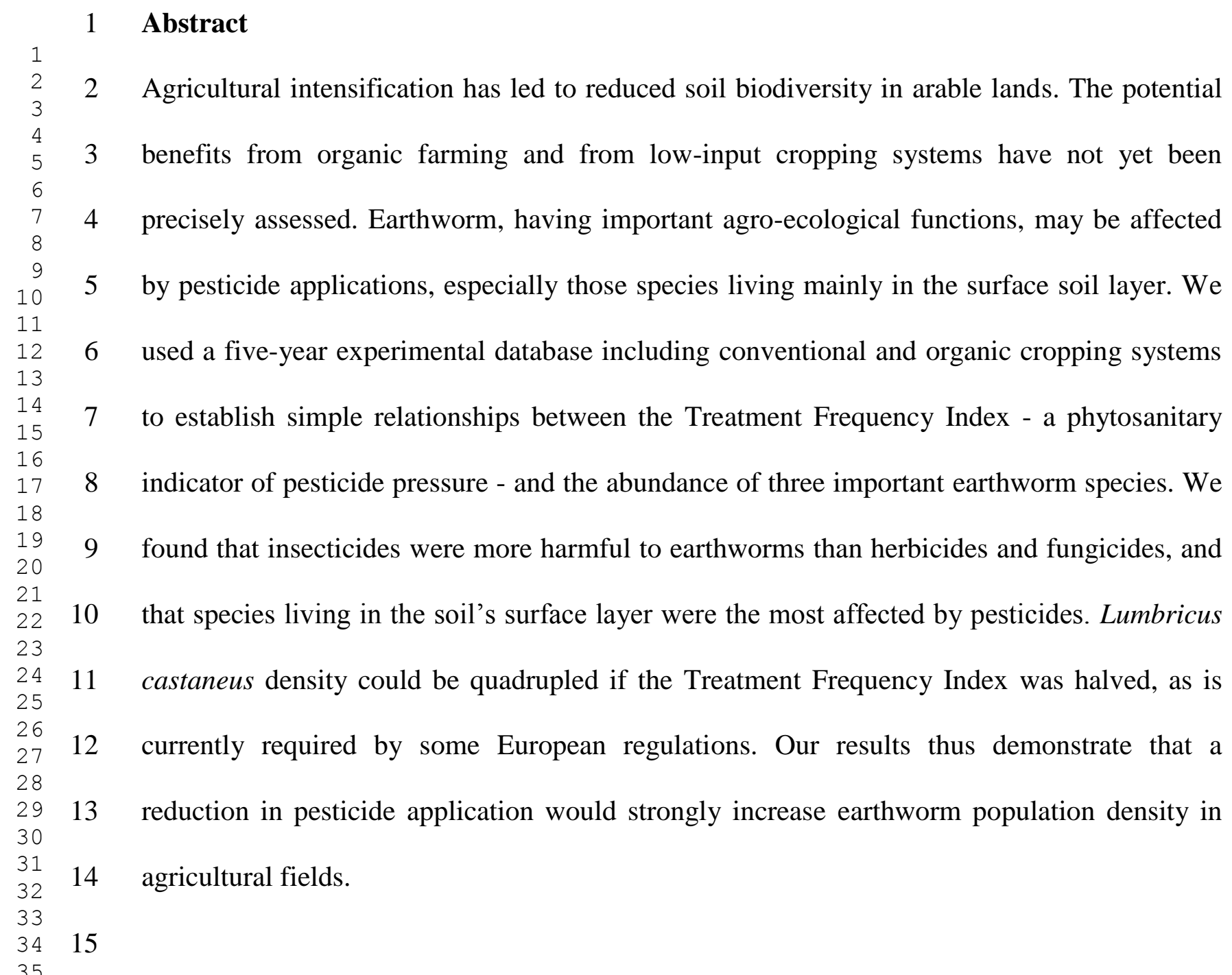

16 Keywords: Earthworm density; Treatment Frequency Index; Organic farming; Conventional 17 cropping system; Pesticides 


\section{Introduction}

Agricultural intensification has reduced soil biodiversity in cultivated fields (Bengtsson et al., 2005; Doran and Zeiss, 2000; Hubbard et al., 1999). Organic and low-input cropping systems have been proposed as alternatives to intensive agricultural practices to limit the impact of chemicals on human health and on the environment (Bengtsson et al., 2005; Hole et al., 2005). However, the effects of a reduction of pesticide applications on biodiversity and particularly on soil organisms need further investigation (Hole et al., 2005).

Earthworms represent a large proportion of soil biomass, i.e. up to $80 \%$ of fresh weight (Yasmin and D’Souza, 2010) and ensure important agro-ecological functions since they influence organic matter dynamics and soil structure (Edwards and Bohlen, 1996; Sims and Gerard, 1999). Earthworms are recognized as ecosystem engineers because they influence the availability of resources to other species (Jones et al., 1994) and have positive effects on organic matter dynamics and soil structure (Edwards and Bohlen, 1996). They are also considered as bioindicators of soil biological functioning (Paoletti, 1999). Bouché (1972) separated earthworms into three categories, based on morphological and behavioral characteristics. Epigeic species, e.g. Lumbricus castaneus, are litter-dwellers living and feeding on or near the soil surface. Anecic earthworms live in permanent vertical burrows within the soil and may emerge to feed on surface litter, e.g. Lumbricus terrestris. Endogeic species e.g., Allolobophora chlorotica, live in temporary horizontal burrows and feed on the soil. This species is geophagous since it gains its nutrients by eating the soil and the green morph is characterized by Bouché (1972) as more epigeic.

Laboratory studies have shown that earthworms are exposed to pesticides through ingestion or epidermal contact (Rodriguez-Castellanos and Sanchez-Hernandez, 2007; Yasmin and D'Souza, 2010). Little is known about the effects of earthworm exposure to pesticides in cultivated fields because most studies were conducted under laboratory 
1 conditions (Frampton et al., 2006; Yasmin and D'Souza, 2010) and cannot be easily 2 extrapolated to field conditions (Lowe and Butt, 2007; Svendsen and Weeks, 1997). Field 3 studies which compared earthworm communities in organic and conventional systems have 4 shown variable results (Hole et al., 2005; Nuutinen and Haukka, 1990), mainly due to 5 confounding factors such as variation in soil tillage, manure inputs or crop types (Hole et al., 6 2005). We decided to study the effect of pesticide use in agricultural fields involving 7 conventional plowing and the same crop, i.e. winter wheat, on three earthworm species: $L$. 8 castaneus, L. terrestris and A. chlorotica which are widespread in Europe and variably in 9 contact with the soil surface and thus potentially exposed to pesticides (Römbke et al., 2004). 10 These species belong to the three ecological categories mentioned above and are involved in 11 the decomposition of surface and soil organic matter and in soil structure maintenance.

12 Pesticide risk assessment for human health and the environment has become a major 13 concern for scientists, politicians and civil society (Pingault et al., 2009; Sattler et al., 2007). 14 In Denmark the Treatment Frequency Index (TFI) was developed (Gravesen, 2003; 15 Jørgensen, 1999; Jørgensen and Kudsk, 2006) for the assessment of pesticide pressure at 16 different scales, from field to national level (Butault et al., 2011; Ferti Ouest 88, 2009). TFI is 17 defined as the mean number of treatments per hectare with commercial products, weighted by 18 the ratio of the dose used to the recommended dose (Pingault, 2007). TFI is easy to calculate 19 and operational at different levels, since it allows the aggregation of very different substances 20 to measure overall phytosanitary pressure (Butault et al., 2011). This indicator requires 21 investigations on pesticide use in agricultural fields.

22 This study aims at i) establishing statistical relationships between the pressure indicator 23 TFI and impact indicators for soil fauna, i.e. densities of three earthworm species variably in 24 contact with the soil surface, ii) using these relationships to estimate threshold values of TFI 
1 leading to an effect on earthworm densities, and iii) using these relationships to estimate the

2 effects of reduced pesticide use on earthworm densities.

3

\section{Materials and methods}

\subsection{Sites and cropping systems}

Field data were collected for 15 site-years with conventional cropping systems and 15 site-years with organic systems. A site-year is a unique combination of a site and a year. Study sites were located in two agricultural areas of the Ile-de-France region and sampled between 2005 and 2012 (Appendix A).

Eleven conventional and eleven organic sites were studied in 2012 in the department of Seine-et-Marne, east of Paris, on clay loamy soils with $70 \%$ silt, $25 \%$ clay and 5\% sand and a neutral pH (Appendix A).

Four conventional site-years and four organic site-years were studied in 2005, 2006, 2007 and 2011 from a trial located in Versailles, $15 \mathrm{~km}$ south-west of Paris, on silty clay soils with $58 \%$ of silt, $17 \%$ of clay and $25 \%$ of sand and a neutral $\mathrm{pH}$ (Appendix A).

No significant differences of texture, $\mathrm{pH}$, organic matter and $\mathrm{C} / \mathrm{N}$ ratio were found ( $p>0.05$ ) between organic and conventional systems (ANOVA, R version 2.15.3, 2013, data from Appendix A).

The climate in both study areas is oceanic temperate with a mean annual precipitation of $640 \mathrm{~mm}$ and a mean annual temperature of $10.4^{\circ} \mathrm{C}$.

A conventional plowing at $25-30 \mathrm{~cm}$ depth was performed in all fields, at a frequency ranging from every year to once every three years. The last plow was performed in 2010 or 2011, depending on the fields. All fields were cultivated with winter wheat at the time of sampling. The levels of mineral fertilizers applied were quite similar across conventional fields. No organic input was applied in organic and conventional fields in Versailles. In Seine- 
1 et-Marne, six organic fields and six conventional fields received organic inputs (poultry and

2 cattle manure, vegetable wastes or vinasse depending on the field). Some farms included both

3 fields under organic and conventional farming. This may explain why organic inputs were

4 similar. Moreover, the number of organic applications and the density of the three earthworm

$5 \quad$ species were not significantly correlated.

6

7

\subsection{TFI calculation}

Based on surveys conducted with field managers (farmers in Seine-et-Marne or the trial manager in Versailles), the name of the pesticides used, including insecticide, herbicide and fungicide treatments, the number of applications and the rate applied to the fields were used to calculate the TFI. The index was calculated over one year before each sampling date because mean Dissipation Time 50 (DT50) and mean DT90 in the field (i.e. time for respectively 50\% and $90 \%$ disappearance of the active ingredients applied at specific initial concentrations in the field, in all our experimental fields), were respectively 2 and 8.5 months (PPDB, 2012) (Appendix B).

TFI was calculated using the following formula: $\mathrm{TFI}_{\text {field }}=\Sigma(\mathrm{AD} / \mathrm{HD})$, where $\mathrm{AD}$ is the amount of pesticide applied in a field per hectare and HD is the recommended rate per hectare (Ministère de l'Agriculture et de la Pêche, 2008). Four types of TFI were calculated, namely TFI Herbicide, TFI Insecticide, TFI Fungicide and TFI Total which is the sum of the three TFIs (Appendix C). TFIs are equal to 0 in organic fields because no chemical pesticides were applied.

\subsection{Earthworm sampling method}

Sampling was performed on each site on ten replicates in 2005, 2006, 2007 and 2011, and on three replicates in 2012 (see Appendix A for sites concerned) using both chemical 
1 extraction and hand-sorting of earthworms (Pelosi et al., 2009). After removing the vegetation

2 on the ground surface, two applications of 3.21 of a diluted expellant solution of allyl

3 isothiocyanate (AITC) was applied to the soil at 10-min intervals within a $40 \mathrm{x} 40 \mathrm{~cm}$ metal

4 frame. AITC was first diluted with isopropanol (propan-2-ol) to obtain a $5 \mathrm{~g} \mathrm{l}^{-1}$ solution 5 (Pelosi et al., 2009; Zaborski, 2003). This solution was then diluted with water to reach a 6 concentration of $0.1 \mathrm{~g} \mathrm{l}^{-1}$. After collecting emergent individuals during 20 minutes, a $40 \mathrm{~cm} \mathrm{x}$ $740 \mathrm{~cm} \times 20 \mathrm{~cm}$-depth block of soil was excavated and remaining earthworms were hand8 sorted from the soil. Earthworms were preserved in $4 \%$ formalin solution. All individuals

9 (juveniles, sub-adults and adults) were counted. Sub-adults and adults were identified at

\subsection{Statistical Analysis}

The response variable was the density of earthworms per $\mathrm{m}^{2}$. This variable was related to TFI using two statistical methods. The first method was based on Poisson log-linear regression. A Poisson model relating earthworm density to TFI was fitted for each species using the glm function of R (Venables and Ripley, 2002). A separate regression model was 
1 fitted for each type of TFI (corresponding to herbicide, insecticide, fungicide separately, and

2 to all three pesticides together) leading to four different regression models per earthworm

3 species. Each model relates the expected earthworm density to TFI as follows:

$4 \quad E\left(Y_{i}\right)=e^{\alpha_{i}+\beta_{i} T F I}$

5 where $Y_{i}$ is the density of earthworms of species $i, \mathrm{E}($.$) is the expected value, \alpha_{i}$ and $\beta_{i}$ are two 6 parameters corresponding to the $\log$ density for TFI $=0$ (i.e., maximum of the $\log$ density if $\beta_{i}$ $7 \quad<0)$ and to the TFI effect respectively. Estimated parameter values, their standard deviations, 8 and their associated p-values were used to analyze the effect of TFI on earthworm density and 9 its interaction with the species. In order to assess the robustness of the results to the dataset characteristics, parameter estimation was repeated with a restricted dataset including the 22 sites located in Seine-et-Marne. The Akaike Information Criterion (AIC) was computed for model with and without TFI variables and models including TFI showed better (i.e., lower) AIC values. The significance of the differences of the estimated TFI-effects across species was tested by including a species-effect and a TFI-effect (main effect and interaction) in the Poisson log-linear regression model, and by testing the significance of the interaction. The fitted models were used in three different ways. First, the models were used to estimate earthworm densities for low and high TFI values (equal to the $1^{\text {st }}$ and $3^{\text {rd }}$ quartiles of TFI data of our dataset respectively). Second, the models were used to calculate the TFI values leading to $50 \%$ and $75 \%$ of the earthworm densities obtained for $\mathrm{TFI}=0$ (i.e, without pesticide application). Third, the models were used to assess the consequences of a reduction of 50\% of the mean TFI values measured in France in 2006 according to Jacquet et al. (2006).

In the second method, a non-parametric technique was used to estimate the relationship between earthworm density and TFI. A polynomial quadratic regression was fitted locally using the loess function of $\mathrm{R}$ (Cleveland et al., 1992). With this approach, a quadratic function is fitted locally at each TFI value $\mathrm{x}$ using data weighted by their distance to $\mathrm{x}$. As the 
1 quadratic function is applied locally, the overall relationship between density and TFI can

2 take various shapes depending on the data distribution. Local regression was applied for each

3 type of TFI and each earthworm species separately. Like Poisson regression models, fitted

4 response curves were used to estimate earthworm densities for low and high TFI values and to 5 estimate TFI thresholds.

6 Contrary to Poisson regression, the non-parametric method does not rely on any 7 assumption about the probability distribution of the data. However, non-parametric methods 8 generally produce less accurate estimated values with small datasets. Results obtained with

9 the two methods were compared in order to assess the robustness of the conclusions to the statistical technique used to analyze the data.

\section{3. Results}

13 A. chlorotica, L. castaneus, and L. terrestris densities ranged from 0 to 135,105 , and 44 14 individuals $\mathrm{m}^{-2}$, respectively, and the TFI Total in conventional sites ranged from 1.6 to 7.0 $15($ mean $=4.1)($ Fig. 1$)$. When TFI Total was 0 , mean values of earthworm densities were 25.0 $16 \pm 37.8,7.5 \pm 27.0$, and $5.6 \pm 12.4$ individuals $\mathrm{m}^{-2}$ for A. chlorotica, L. castaneus, and $L$. 17 terrestris respectively (Fig. 1).

18 Estimated values of $\beta_{i}$ i.e., TFI effect on earthworm density, are presented in Table 1. The values of this parameter correspond to the effects of a one-unit increase of TFI on the log earthworm density. TFI Total, TFI Herbicide, TFI Insecticide, and TFI Fungicide exerted significant negative effects on earthworm densities for the three considered species (Table 1). TFI effect differed significantly between the three species for all TFI categories $(\mathrm{p}<0.05)$, and was invariably higher for $L$. castaneus for all the TFIs compared to $L$. terrestris and A. chlorotica. TFI effects were always the lowest for A. chlorotica, effects on L. terrestris being intermediate (Table 1). 
The effect of TFI Insecticide was the largest for all three species (Table 1). For $L$. castaneus, TFI Fungicide had a stronger effect than TFI Herbicide while the opposite result was obtained for L. terrestris and A. chlorotica (Table 1). In order to assess the robustness of the results to the dataset characteristics, parameter estimation was repeated with a dataset restricted to the 22 sites located in Seine-et-Marne. Results obtained with the full and the restricted datasets are compared in Table 1. The results obtained for A. chlorotica and $L$. terrestis show that the TFI effect is still significant $(\mathrm{p}<0.05)$ even when the data obtained in the trial are excluded from the analysis. The ranking of these species are similar with the full and the restricted datasets for all type of TFI. In addition, results obtained with the restricted dataset confirm that TFI Insecticide had a stronger effect on earthworm density than the other types of TFI. It was not possible, to fit the model for $L$. castaneus with the restricted dataset because only one non-zero data was included in this dataset for this species.

With the Poisson regression model, densities of $L$. castaneus reached values below 1 individual $\mathrm{m}^{-2}$ when TFI Total, TFI Herbicide, TFI Insecticide, and TFI Fungicide were 2.8, 1.7, 0.9, and 1.0 respectively. Estimated density for $L$. terrestris reached values below 1 individual $\mathrm{m}^{-2}$ when TFI Total, TFI Herbicide, and TFI Insecticide were 5.8, 2.9, and 1.9, respectively but did not reach values below 1 individual $\mathrm{m}^{-2}$ for TFI Fungicide values considered in our dataset (Fig. 2). Estimated densities of A. chlorotica were always above 1 individual $\mathrm{m}^{-2}$ for the observed TFI values, but strongly decreased at high TFI. A. chlorotica densities were $23.7 \%, 18.6 \%, 31.8 \%$ and $43.4 \%$ of the maximum estimated density values when TFI Total, TFI Herbicide, TFI Insecticide, and TFI Fungicide reached the highest values reported in the dataset (Fig. 2).

Results obtained with the two statistical methods were similar (Table 2). Earthworm densities estimated for TFI $=0$ using Poisson and non-parametric regressions were almost identical. When TFI Total, TFI Herbicide, TFI Insecticide, and TFI Fungicide were 4.5, 2.4, 
1 1.0, and 1.0 respectively (i.e. the third quartiles of TFI in the dataset), Poisson and non-

2 parametric models again showed similar earthworm density values (Table 2). Differences

3 were greater for the density estimates obtained for A. chlorotica and for the third quartile of

4 TFI Herbicide and Fungicide. In this case, the Poisson models led to a lower estimate of $A$.

5 chlorotica density for the third quartile of TFI Herbicide and to higher estimated density for

6 the third quartile of TFI Fungicide (Table 2) compared to non-parametric estimated values.

7 Standard errors of non-parametric models were higher than those obtained with Poisson

8 models, due to the relatively small size of our dataset (Table 2).

9 Using both models, threshold values to maintain $50 \%$ and $75 \%$ of the maximum density 10 of the three species were calculated for the four TFI categories (Table 3). Each species 11 showed different threshold values for the four TFI categories, L. castaneus showing the 12 lowest thresholds (except in one case, for TFI Insecticide with the non-parametric model, 13 where thresholds for $50 \%$ of the maximum density for L. castaneus and L. terrestris were 0.3 14 and 0.2 respectively) and A. chlorotica usually the highest ones (except for TFI Total and TFI 15 Herbicide with the non-parametric model, for which thresholds for L. terrestris were higher 16 than those of A. chlorotica). Intermediate threshold values were obtained for L. terrestris. The 17 lowest threshold values were usually obtained for TFI Insecticide (except for $50 \%$ of $A$. 18 chlorotica maximum density with the non-parametric model, where thresholds of TFI 19 Insecticide and TFI Fungicide were 0.9 and 0.5 respectively).

20 According to Jacquet et al., (2011), mean TFI Total in 2006 in France was 3.8, which 21 corresponds to an estimated density of $0.5 \pm 0.2,2.3 \pm 0.4$, and $11.4 \pm 0.9$ individuals $\mathrm{m}^{-2}$ for 22 L. castaneus, L. terrestris, and A. chlorotica respectively, using Poisson models (Table 4). 23 According to the fitted models, 50\% reduction of the TFI target (proposed by the French 24 government for 2018, Butault et al., 2011) would increase L. castaneus, L. terrestris, and A. chlorotica densities by a factor $3.8,1.4$, and 1.5 according to Poisson models and by a factor 
$14.8,1.5$, and 1.5 according to the non-parametric method, compared to values estimated for

2 TFI in 2006 (Table 4). Pesticide reduction objectives set up in Denmark in 2009 are close to

3 French target values for 2018 and lead to similar earthworm densities (Table 4).

\section{Discussion}

Earthworm density values found in this study were in the same range as values reported by other authors in plowed cultivated fields (Berry and Karlen, 1993; Schmidt et al., 2001). We found that densities were higher for A. chlorotica than for L. castaneus and L. terrestris, a well-known relationship between soil invertebrates of increasing size (Petersen and Luxton, 1982). Moreover, earthworms, especially anecics and epigeics, may be less abundant because plowing affects earthworms directly through mechanical damage or exposure to predation as well as indirectly through consequent changes in the soil environment. These changes include destruction of burrows, loss of surface organic matter, and changes in soil physical conditions such as water content and temperature (Chan, 2001; Edwards and Bohlen, 1996).

The three ecological categories of earthworms, represented by the three studied species, were all reduced in number by pesticides but $L$. castaneus seemed to be the most sensitive species, followed by L. terrestris and finally A. chlorotica. Estimated earthworm densities reached zero at the highest TFI values reported in our dataset, except for A. chlorotica. Apart from the work of Rault et al. (2007), who demonstrated that L. castaneus, together with $L$. terrestris, exhibited the strongest physiological reaction to pesticide exposure when compared with endogeic and endo-anecic species, little is known about the sensitivity of L. castaneus to pesticides. However, according to Culy and Berry (1995) and other authors (Edwards and Bohlen, 1996; Lofs-Holmin, 1981; Römbke et al., 2004; Tu et al., 2011; Van Gestel, 1992), earthworms feeding on or near the soil surface are more affected by pesticides than those feeding deeper in the soil. This may be explained by the fact that most pesticides applied in 
1 cultivated fields stay in the top $2.5 \mathrm{~cm}$ (Van Gestel, 1992). L. castaneus has a higher exposure

2 to pesticides than the two other species considered in this study, in particular when compared

3 with A. chlorotica. L. terrestris, although living in deep soil layers, feeds on surface organic

4 matter such as leaf litter while A. chlorotica lives in the first five centimeters of the soil,

5 feeding on soil organic matter in the mineral layer. Our study suggests that the more time an

6 earthworm species spends on or near the soil surface, the more it is affected by pesticide 7 application.

8 Different assumptions may be made to explain lower earthworm densities with increasing

9 pesticide applications. Firstly, some compounds may have lethal effects (acute toxicity), even at recommended rates, due for instance to accumulation of maximum-rate treatments (Fayolle 11 and Stawiecki, 1990; Ruppel and Laughlin, 1977). Moreover, pesticides may affect 12 earthworm fecundity and growth (chronic toxicity), leading to a long-term decrease in 13 earthworm abundance (Yasmin and D'Souza, 2010). Furthermore, earthworms, being reactive 14 to the quality of their environment, can move away to avoid unsuitable conditions (Mathieu et 15 al., 2010). Individuals could thus escape from polluted fields. Epigeic species seem to have 16 better dispersal capabilities than anecic species, which in turn disperse better than endogeics 17 (Eijsackers, 2010). For instance, Eijsackers (2010) showed that the epigeic L. rubellus 18 dispersed much better than the endogeic A. chlorotica and even than the anecic L. terrestris. 19 Finally, the number of pesticide applications is likely to be positively related to the amount of 20 field traffic which could add negative effects on earthworm populations (Hansen and 21 Engelstad, 1999), especially on epigeic densities.

22 According to our results, insecticides seem to be the most harmful to the three earthworm 23 species, followed by herbicides and then by fungicides. Jänsch et al. (2006) reviewed 92 24 studies dealing with insecticides, of which 60 revealed depressive effects of insecticides on 25 earthworm densities. Tu et al. (2011) reported that a single application of insecticides i.e., 
1 carbaryl and imidacloprid, applied at "manufacturer's suggested dose" significantly inhibited

2 the activity of earthworm communities in the field. Our results confirm that insecticide use

3 has to be decreased in first instance, prior to herbicides and fungicides, if we want to alleviate

4 most pesticide effects harmful to earthworms living in contact with the soil surface.

5 Concerning herbicides, Jänsch et al. (2006) and others (Edwards and Bohlen, 1996; Lee, 6 1985) reported no effect on Lumbricidae. In our study, TFI Herbicide reduced densities of 7 species in contact with the soil surface. Herbicides may cause community reduction by 8 reducing sources of organic matter (leaf and root litter) on which earthworms feed. Authors

9 who studied herbicide effects on earthworms have shown relatively few harmful responses of 10 earthworms but they generally worked under laboratory conditions, not taking into account 11 repeated applications, cocktail (synergistic) effects, and indirect effects like interactions 12 between pesticides and natural stress factors which may have deleterious effects on 13 earthworm populations (Holmstrup et al., 2010; Santos et al., 2011; Zhou et al., 2011).

14 Finally, in our study, fungicides seemed to have a smaller effect on L. terrestris and A. 15 chlorotica densities than insecticides and herbicides. Jänsch et al. (2006) highlighted the 16 harmful effect of fungicides on Lumbricidae in 50\% of the reviewed studies i.e. 106 17 publications dealing with fungicides. Tu et al. (2011) explained that some fungicides they 18 tested and that occurred in our study sites, i.e., thiophanatemethyl, propiconazole, 19 chlorothalonil, and azoxystrobin, did not show significant toxicity to earthworms when 20 applied only once, but their toxicity increased with application frequency.

21 Other factors than TFI are likely to influence earthworm density in agricultural fields, 22 especially soil tillage and fertilization. It was not possible to investigate the effect of these 23 factors in details because the experimental design was not appropriate to test the effect of 24 tillage and fertilization. As tillage practices were similar in all site-years, it was not possible 25 to use our dataset to estimate tillage effect. The effect of fertilization type (organic vs. non- 
1 organic) was tested in our paper but, as no detailed information on the quantity of each type of

2 fertilizer applied by the farmers was available, it was not possible to include fertilizer dose as

3 a covariable in our statistical model. In addition, even if information on fertilizer doses had

4 been available, the inclusion of this information in the statistical model would be difficult

5 because each type of organic fertilizer has its own characteristics. Risk of confounding effect

6 can never be considered equal to zero, but this risk is limited in our dataset because the

$7 \quad$ selected fields differ mainly by their TFI values.

8 The average TFI Total for French farms specializing in field crops was 3.8 in 2006. The

9 objective of reducing the use of pesticides by 50\%, planned in the "Ecophyto2018 plan" in

10 France (Jacquet et al., 2011), would mean that all French agriculture should convert to 11 integrated farming, which will require significant effort (Butault et al., 2011). Integrated 12 farming involves the limitation of pesticide and mineral fertilizer use by means of alternative 13 cultural techniques, e.g. organic manures, longer rotations, and accurate monitoring of 14 diseases and deficiencies. In the studied fields, approximately the same number of organic 15 inputs was used in conventional and organic cropping systems. Moreover, at the rates applied 16 in the studied sites (data not shown), mineral fertilizers are generally not harmful to 17 earthworms (Whalen et al., 1998) and may even be indirectly beneficial to them by increasing 18 the quantity of crop residues returned to the soils (Edwards et al., 1995). In the case of a 50\% 19 reduction in pesticide use in 2018, TFI Total would be in the range $1.9-2.5$ according to 20 Jacquet et al. (2011). Our models show that, if the Treatment Frequency Index was halved 21 compared to the value obtained in 2006 , as is currently required by some European 22 regulations, then the densities of $L$. castaneus, $L$. terrestris, and A. chlorotica would increase 23 by a factor $4.8,1.5$, and 1.5 respectively. An increase in density of these three earthworm 24 species would favor the provision of ecosystem services such as biogeochemical cycling, soil 25 structure maintenance and water infiltration. 
2 prevailing pest level in fields. In our study context, this index is convenient for calculating

3 and comparing pesticide usage between fields. Compared to the commonly used index 'total

4 amount of pesticides', it provides relevant information on environmental risks due to

5 pesticides usage as doses applied are standardized to the recommended application rate. Also,

6 TFI accounts for all active molecules composing pesticides and is weighted by the percentage

7 of the treated area. However, it does not account for the chemical and toxic properties of some

8 specific substances composing pesticides which can influence pesticide's effect on the

9 environment. Moreover, different pesticide regimes may lead to similar TFI because

10 pesticides have different homologated doses. There is thus no direct relationship between the 11 number of applied doses and TFI values. Assessing environmental effect of each substance in

12 a single statistical model would have been interesting but it was impossible due to over13 parameterization issues.

14 To evaluate the risks on biological populations linked to pesticide application, 15 ecotoxicological laboratory experiments use different indicators based on survival and reproduction as endpoints, e.g. concentrations affecting $50 \%$ of exposed individuals $\left(\mathrm{LC}_{50}\right.$ for survival or $\mathrm{EC}_{50}$ for reproduction) or No Observed Effect Concentration (NOEC), but they are insufficient to extrapolate these effects to natural conditions (Baveco and De Roos, 1996). The final outcome, in terms of the damage inflicted on natural populations, depends on ecological relationships between earthworm species and the local physical, chemical and biological properties of the site (Baveco and De Roos, 1996). Here, relationships between pressure and impact bioindicators were calculated from doses applied according to current farming practices. These relationships may help in establishing objectives for reducing pesticide use according to required earthworm densities. An interesting perspective could be 
1 to explore whether these relationships would be maintained in fields involving different types

2 of management, such as other crops and other types of tillage management.

3

\section{5. Conclusion} surface.

\section{References}

This study demonstrated a negative relationship between TFI, a common and easilycalculated pesticide pressure indicator, and an impact bioindicator, earthworm density. Using data collected in agricultural fields, we found that earthworm species living in close contact with the soil surface were the most affected by pesticide application. The statistical relationships established in this paper are useful for predicting the effect of an increase or a decrease of TFI of three different families of pesticides on three different earthworm species. We found that a $50 \%$ reduction of pesticide use is likely to lead to large increases (i.e. up to 4.8 times more) in earthworm density and that insecticide use has to be managed as a priority to reduce the most negative effects on earthworm populations living in contact with the soil

\section{Acknowledgements}

We would like to thank all the people who participated in the earthworm sampling and especially Jodie Thénard, Félix Fraillon, Françoise Elsass and Nathalie Cheviron, and also the Fédération Ile-de-France de Recherche sur l'Environnement (FIRE, FR3020), and the Agence Nationale pour la Nature et la Biodiversité en Ile-de-France (NatureParif) for their financial support. We would also like to thank Alan Scaife for revising the English language.

Baveco, J.M., de Roos, A.M., 1996. Assessing the impact of pesticides on lumbricid populations: an individual-based modelling approach. J. Appl. Ecol. 33, 1451-1468. 
Bengtsson, J., Ahnstrom, J., Weibull, A.C., 2005. The effects of organic agriculture on

2 biodiversity and abundance: a meta-analysis. J. Appl. Ecol. 42, 261-269.

3 Berry, E.C., Karlen, D.L., 1993. Comparisons of alternative farming systems. II.

4 Earthworm population density and species diversity. Am. J. Alternative Agr. 8, 21-26.

Butault, J.-P., Delame, N., Jacquet, F., Zardet, G. 2011. L'utilisation des pesticides en France : état des lieux et perspectives de réduction. Notes et Études Socio-Économiques 35, $1-24$.

Chan, K.Y., 2001. An overview of some tillage impacts on earthworm population abundance and diversity - implications for functioning in soils. Soil Tillage Res. 57, 179-191.

Cleveland, W.S., Grosse, E. Shyu, M.J., 1992. Local regression models, in: Chambers, J.M. Hastie, T. (Eds.), Statistical Models in Chapman and Hall, New York, pp. 309-376.

Culy, M.D., Berry, E.C., 1995. Toxicity of soil-applied granular insecticides to earthworm populations in cornfields. Down to Earth 50, 20-25.

Doran, J.W., Zeiss, M.R., 2000. Soil health and sustainability: managing the biotic component of soil quality. Appl. Soil Ecol. 15, 3-11.

Edwards, C.A., Bohlen, P.J., 1996. Biology and Ecology of Earthworms, 3rd ed. Chapman and Hall, London.

Edwards, C.A., Bohlen, P.J., Linden, D.R., Subler, S. 1995. Earthworms in agroecosystems, in: Hendrix, P.F. (Eds.), Earthworm Ecology and Biogeography in North America. Lewis, Boca Raton, Fla, pp. 185-213.

Eijsackers, H., 2010. Earthworms as colonisers: primary colonisation of contaminated land, and sediment and soil waste deposits. Sci. Total Environ. 408, 1759-1769.

Fayolle, L., Stawiecki, J., 1990. The effect of two molluscicides on earthworms. Phytoma 28-33. 
Ferti Ouest 88. 2009. Calculez votre Indice de Fréquence de Traitement. Fiche $\mathrm{n}^{\circ} 66$, 2 septembre 2009.

3 Frampton, G.K., Jänsch, S., Scott-Fordsmand, J.J., Römbke, J., Van den Brink, P.J., 2006.

4 Effects of pesticides on soil invertebrates in laboratory studies: A review and analysis using $5 \quad$ species sensitivity distributions. Environ. Toxicol. Chem. 25, 2480-2489.

6 Gravesen, L., 2003. The Treatment Frequency Index: an indicator for pesticide use and 7 dependency as well as overall load on the environment. Pesticide Action Network Europe, 8 Pure conference, Copenhagen, Denmark.

9 Hansen, S., Engelstad, F., 1999. Earthworm populations in a cool and wet district as 10 affected by tractor traffic and fertilisation. Appl. Soil Ecol. 13, 237-250.

11 Hole, D.G., Perkins, A.J., Wilson, J.D., Alexander, I.H., Grice, P.V., Evans, A.D., 2005. 12 Does organic farming benefit biodiversity? Biol. Conserv. 122, 113-130.

13 Holmstrup, M., Bindesbøl, A.-M., Oostingh, G.J., Duschl, A., Scheil, V., Köehler, H.-R., 14 Loureiro, S., Soares, A.M.V.M., Ferreira, A.L.G., Kienle, C., Gerhardt, A., Laskowski, R., 15 Kramarz, P.E., Bayley, M., Svendsen, C. Spurgeon, D.J., 2010. Interactions between effects 16 of environmental chemicals and natural stressors: a review. Sci. Total Environ. 408, 3746173762.

18 Hubbard, V.C., Jordan, D., Stecker, J.A., 1999. Earthworm response to rotation and tillage 19 in a Missouri claypan soil. Biol. Fertil. Soils. 29, 343-347.

20 Jänsch, S., Frampton, G.K., Römbke, J., Van den Brink, P.J. Scott-Fordsmand, J.J., 2006. 21 Effects of pesticides on soil invertebrates in model ecosystem and field studies: a review and 22 comparison with laboratory toxicity data. Environ. Toxicol. Chem. 25, 2490-2501.

23 Jacquet, F., Butault, J.P., Guichard, L., 2011. An economic analysis of the possibility of 24 reducing pesticides in French field crops. Ecol. Econ. 70, 1638-1648. 
Jones, C.G., Lawton, J.H. Shachak, M., 1994. Organisms as ecosystem engineers. Oikos. $2 \quad 69,373-386$

3 Jørgensen, L.N., 1999. Denmark's action plans for pesticides: status and role of research.

4 Nordisk Jordbrugsforskning 81, 201-202.

5 Jørgensen, L.N., Kudsk, P., 2006. Twenty years' experience with reduced agrochemical 6 inputs: effects on farm economics, water quality, biodiversity and environment. HGCA 7 Conference, Grantham, UK.

8 Lee, K.E., 1985. Earthworms: their Ecology and Relationship with Soils and Land Use. 9 Academic Press, New York.

10 Lofs-Holmin, A., 1981. Influence in field experiments of benomyl and carbendazim on 11 earthworms (Lumbricide) in relation to soil texture. Swed. J. Agric. Res. 11, 141-147.

12 Lowe, C.N., Butt, K.R., 2007. Earthworm culture, maintenance and species selection in 13 chronic ecotoxicological studies: A critical review. Eur. J. Soil Biol. 43, S281-S288.

14 Mathieu, J., Barot, S., Blouin, M., Caro, G., Decaëns, T., Dubs, F., Dupont, L., Jouquet, P. 15 Nai, P., 2010. Habitat quality, conspecific density, and habitat pre-use affect the dispersal 16 behaviour of two earthworm species, Aporrectodea icterica and Dendrobaena veneta, in a 17 mesocosm experiment. Soil Biol. Biochem. 42, 203-209.

18 Ministère de l'Agriculture et de la Pêche, 2008. URL: http://driaf.ile-de19 france.agriculture.gouv.fr/IMG/pdf_presentation_IFT_cle4535d3.pdf.

20 Nuutinen, V., Haukka, J., 1990. Conventional and organic cropping systems at Suitia. VII: 21 Earthworms. J. Agr. Sci. Finland 62, 357-367.

22 Paoletti, M.G., 1999. The role of earthworms for assessment of sustainability and as 23 bioindicators. Agr. Ecosyst. Environ. 74, 137-155. 
Pelosi, C., Bertrand, M., Capowiez, Y., Boizard, H. Roger-Estrade, J., 2009. Earthworm

2 collection from agricultural fields: Comparisons of selected expellants in presence/absence of 3 hand-sorting. Eur. J. Soil Biol. 45, 176-183.

4 Petersen, H., Luxton, M. 1982. A comparative analysis of soil fauna populations and their 5 role in decomposition processes. Oikos 39, 287-388.

6 Pingault, N. 2007. Améliorer la qualité de l'eau : un indicateur pour favoriser une 7 utilisation durable des produits phytosanitaires. MAP, 10 p. URL: 8 http://agriculture.gouv.fr/IMG/pdf/V3TAPButault7a26.pdf.

9 Pingault, N., Pleyber, E., Champeaux, C., Guichard, L., Omon, B. 2009. Produits 10 phytosanitaires et protection intégrée des cultures : l'indicateur de fréquence de traitement 11 (IFT). Notes et Études Socio-Économiques 32, 61-94.

12 PPDB, 2012. http://sitem.herts.ac.uk/aeru/footprint/fr/index.htm.

13 Rault, M., Mazzia, C., Capowiez, Y., 2007. Tissue distribution and characterization of 14 cholinesterase activity in six earthworm species. Comp. Biochem. Physiol. 147, 340-346.

15 Rodriguez-Castellanos, L., Sanchez-Hernandez, J.C., 2007. Earthworm biomarkers of 16 pesticide contamination: current status and perspectives. J. Pestic. Sci. 32, 360-371.

17 Römbke, J., Van Gestel, C.A.M., Jones, S.E., Koolhaas, J.E., Rodrigues, J.M.L., Moser, 18 T., 2004. Ring-testing and field-validation of a Terrestrial Model Ecosystem (TME) - an 19 instrument for testing potentially harmful substances: effects of carbendazim on earthworms. 20 Ecotoxicology. 13, 105-118.

21 Ruppel, H.F., Laughlin, C.W., 1977. Toxicity of soil pesticides to earthworms. J. Kans. 22 Entomol. Soc. 50, 113-118.

23 Santos, M.J.G., Morgado, R., Ferreira, N.G.C., Soares, A.M.V.M., Loureiro, S., 2011. 24 Evaluation of the joint effect of glyphosate and dimethoate using a small-scale terrestrial 25 ecosystem. Ecotoxicol. Environ. Saf. 74, 1994-2001. 
Sattler, C., Kächele, H., Verch, G., 2007. Assessing the intensity of pesticide use in 2 agriculture. Agr. Ecosyst. Environ. 119, 299-304.

3 Schmidt, O., Curry, J.P., Hackett, R.A., Purvis, G. Clements, R.O., 2001. Earthworm 4 communities in conventional wheat monocropping and low-input wheat-clover intercropping $5 \quad$ systems. Ann. Appl. Biol. 138, 377-388.

6 Sims, R.W., Gerard, B.M., 1999. Earthworms. FSC Publications, London.

7 Svendsen, C., Weeks, J.M., 1997. A simple low-cost field mesocosm for ecotoxicological 8 studies on earthworms. Comp. Biochem. Physiol. C-Pharmacol. Toxicol. Endocrinol. 117, 31940.

10 Tu, C., Wang, Y., Duan, W., Hertl, P., Tradway, L., Brandenburg, R., Lee, D., Snell, M. $11 \mathrm{Hu}, \mathrm{S} ., 2$ 2011. Effects of fungicides and insecticides on feeding behavior and community 12 dynamics of earthworms: Implications for casting control in turfgrass systems. Appl. Soil 13 Ecol. 47, 31-36.

14 Van Gestel, C.A.M., 1992. Validation of earthworm toxicity tests by comparison with field 15 studies: a review of benomyl, carbendazim, carbofuran, and carbaryl. Ecotoxicol. Environ. 16 Saf. 23, 221-236.

17 Venables, W.N., Ripley, B.D. 2002. Modern Applied Statistics with S. Springer, New 18 York.

19 Whalen, J.K., Parmelee, R.W., Edwards, C.A., 1998. Population dynamics of earthworm 20 communities in corn agroecosystems receiving organic or inorganic fertilizer amendments. 21 Biol. Fertil. Soils. 27, 400-407.

22 Yasmin, S., D'Souza, D., 2010. Effects of pesticides on the growth and reproduction of 23 earthworm: a review. Appl. Environ. Soil Sci. doi:10.1155/2010/678360.

24 Zaborski, E.R., 2003. Allyl isothiocyanate: an alternative chemical expellant for sampling 25 earthworms. Appl. Soil Ecol. 22, 87-95. 
1 Zhou, S., Duan, C., Michelle, W.H.G., Yang, F. Wang, X., 2011. Individual and combined 1

2 toxic effects of cypermethrin and chlorpyrifos on earthworm. J. Environ. Sci. 23, 676-680. 
Table 1. Estimated values of the parameter $\beta_{i}$ corresponding to the TFI effect, obtained with Poisson regression models (standard errors of estimated values in brackets), using the four TFI categories and the three earthworm species. TFI means Treatment Frequency Index. All estimated values were significantly different from zero $(\mathrm{p}<0.05)$. Full dataset designates data from all sites (in Seine-et-Marne and Versailles). Restricted dataset designates data from the 22 sites located in Seine-et-Marne.

\begin{tabular}{llcc} 
& & \multicolumn{2}{c}{ Estimated value of $\beta_{\mathrm{i}}$} \\
\cline { 3 - 4 } TFI & Earthworm species & Full dataset & Restricted dataset \\
\cline { 3 - 4 } Total & A. chlorotica & $-0.21(0.02)$ & $-0.23(0.03)$ \\
& L. castaneus & $-0.73(0.12)$ & - \\
& L. terrestris & $-0.31(0.06)$ & $-0.36(0.11)$ \\
\hline Herbicide & A. chlorotica & $-0.38(0.04)$ & $-0.39(0.04)$ \\
& L. castaneus & $-1.17(0.19)$ & - \\
& L. terrestris & $-0.64(0.11)$ & $-0.56(0.17)$ \\
\hline Insecticide & A. chlorotica & $-0.63(0.09)$ & $-0.91(0.13)$ \\
& L. castaneus & $-2.14(0.44)$ & - \\
& L. terrestris & $-0.84(0.22)$ & $-2.0(0.68)$ \\
\hline Fungicide & A. chlorotica & $-0.33(0.07)$ & $-0.54(0.11)$ \\
& L. castaneus & $-1.82(0.37)$ & - \\
& L. terrestris & $-0.36(0.16)$ & $-0.93(0.41)$ \\
\hline
\end{tabular}


Table 2. Estimated values of earthworm densities and standard errors (in brackets) obtained with Poisson and non-parametric models for two TFI values $\left(1^{\text {st }}\right.$ and $3^{\text {rd }}$ quartile for each TFI). These values are listed for each TFI category and each earthworm species. TFI means Treatment Frequency Index.

\begin{tabular}{|c|c|c|c|c|}
\hline Earthworm species & TFI & TFI value & $\begin{array}{l}\text { Earthworm density } \\
\text { (Poisson model) }\end{array}$ & $\begin{array}{c}\text { Earthworm density } \\
\text { (non-parametric model) }\end{array}$ \\
\hline \multirow[t]{8}{*}{ Allolobophora chlorotica } & Total & 0.0 & $25.0(1.2)$ & $25.0(7.5)$ \\
\hline & & 4.5 & $9.8(0.9)$ & $9.9(12.5)$ \\
\hline & Herbicide & 0.0 & $25.3(1.2)$ & $25.1(7.2)$ \\
\hline & & 2.4 & $10.3(0.8)$ & $16.8(13.0)$ \\
\hline & Insecticide & 0.0 & $21.7(1.0)$ & $21.8(6.4)$ \\
\hline & & 1.0 & $11.6(1.0)$ & $11.7(11.9)$ \\
\hline & Fungicide & 0.0 & $20.5(1.0)$ & $22.36 .6)$ \\
\hline & & 1.0 & $14.7(1.0)$ & $6.6(11.5)$ \\
\hline \multirow[t]{8}{*}{ Lumbricus castaneus } & Total & 0.0 & $7.6(0.7)$ & $7.5(5.1)$ \\
\hline & & 4.5 & $0.3(0.1)$ & $0.3(8.6)$ \\
\hline & Herbicide & 0.0 & $7.3(0.7)$ & $7.2(5.0)$ \\
\hline & & 2.4 & $0.4(0.2)$ & $0.6(8.9)$ \\
\hline & Insecticide & 0.0 & $5.8(0.5)$ & $5.8(4.4)$ \\
\hline & & 1.0 & $0.7(0.3)$ & $0.4(8.1)$ \\
\hline & Fungicide & 0.0 & $5.9(0.5)$ & $6.1(4.5)$ \\
\hline & & 1.0 & $1.0(0.3)$ & $0.0(7.8)$ \\
\hline \multirow[t]{8}{*}{ Lumbricus terrestris } & Total & 0.0 & $5.9(0.6)$ & $5.5(2.4)$ \\
\hline & & 4.5 & $1.5(0.3)$ & $2.2(4.0)$ \\
\hline & Herbicide & 0.0 & $6.1(0.6)$ & $5.9(2.3)$ \\
\hline & & 2.4 & $1.3(0.3)$ & $0.7(4.2)$ \\
\hline & Insecticide & 0.0 & $4.8(0.5)$ & $5.0(2.1)$ \\
\hline & & 1.0 & $2.1(0.4)$ & $1.3(3.8)$ \\
\hline & Fungicide & 0.0 & $4.4(0.5)$ & $4.7(2.1)$ \\
\hline & & 1.0 & $3.1(0.5)$ & $1.7(3.7)$ \\
\hline
\end{tabular}


Table 3. Threshold values of TFI Total, TFI Herbicide, TFI Insecticide and TFI Fungicide to obtain $50 \%$ and $75 \%$ of the maximum estimated earthworm density i.e., when $\mathrm{TFI}=0$, for the three earthworm species. TFI means Treatment Frequency Index.

\begin{tabular}{|c|c|c|c|c|c|c|}
\hline \multirow[b]{2}{*}{ Earthworm species } & \multirow[b]{2}{*}{$\begin{array}{l}\% \text { of the maximum estimated } \\
\text { earthworm density }\end{array}$} & \multirow[b]{2}{*}{ Statistical method } & \multicolumn{4}{|c|}{ Thresholds values of TFI } \\
\hline & & & Total & Herbicide & Insecticide & Fungicide \\
\hline \multirow{4}{*}{ A. chlorotica } & \multirow{2}{*}{$50 \%$} & Poisson model & 3.3 & 1.8 & 1.1 & 2.1 \\
\hline & & Non-parametric method & 3.4 & 3.1 & 0.9 & 0.5 \\
\hline & \multirow{2}{*}{$75 \%$} & Poisson model & 1.4 & 0.8 & 0.4 & 0.9 \\
\hline & & Non-parametric method & 1.4 & 0.7 & 0.2 & 0.2 \\
\hline \multirow{4}{*}{ L. castaneus } & \multirow{2}{*}{$50 \%$} & Poisson model & 0.9 & 0.6 & 0.3 & 0.4 \\
\hline & & Non-parametric method & 1.3 & 0.9 & 0.3 & 0.3 \\
\hline & \multirow{2}{*}{$75 \%$} & Poisson model & 0.4 & 0.2 & 0.1 & 0.2 \\
\hline & & Non-parametric method & 0.6 & 0.4 & 0.1 & 0.1 \\
\hline \multirow{4}{*}{ L. terrestris } & \multirow{2}{*}{$50 \%$} & Poisson model & 2.2 & 1.1 & 0.8 & 1.9 \\
\hline & & Non-parametric method & 4.0 & 1.7 & 0.2 & 0.5 \\
\hline & \multirow{2}{*}{$75 \%$} & Poisson model & 0.9 & 0.4 & 0.3 & 0.8 \\
\hline & & Non-parametric method & 2.5 & 1.1 & 0.1 & 0.2 \\
\hline
\end{tabular}


Table 4. Density predictions of the three earthworm species as a function of the mean TFI Total in France in 2006 (Jacquet et al., 2011), the Denmark objective for 2009 (Pingault et al., 2009) and the France objective for 2018 (Jacquet et al., 2011), using Poisson regression and non-parametric models. TFI means Treatment Frequency Index.

\begin{tabular}{llccc}
\hline \multirow{2}{*}{ Earthworm species Statistical method } & $\begin{array}{c}\text { Mean TFI Total in France } \\
\text { in 2006 (TFI Total = 3.8) }\end{array}$ & $\begin{array}{c}\text { Denmark objective for } \\
\text { 2012 (TFI Total = 1.7) }\end{array}$ & $\begin{array}{c}\text { France objective for } \\
\text { 2018 (TFI Total = 1.9) }\end{array}$ \\
\cline { 1 - 4 } A. chlorotica & Poisson model & $11.4 \pm 0.9$ & $17.6 \pm 0.8$ & $16.8 \pm 0.8$ \\
& Non-parametric method & $11.6 \pm 11.2$ & $17.8 \pm 10.1$ & $17.2 \pm 10.5$ \\
\hline \multirow{2}{*}{ L. castaneus } & Poisson model & $0.5 \pm 0.2$ & $2.2 \pm 0.4$ & $1.9 \pm 0.4$ \\
& Non-parametric method & $0.5 \pm 7.6$ & $2.6 \pm 6.9$ & $2.4 \pm 7.2$ \\
\hline \multirow{2}{*}{ L. terrestris } & Poisson model & $2.3 \pm 0.4$ & $3.5 \pm 0.4$ & $3.3 \pm 0.4$ \\
& Non-parametric method & $3.0 \pm 3.6$ & $4.7 \pm 3.3$ & $4.6 \pm 3.4$ \\
\hline
\end{tabular}


Fig.1
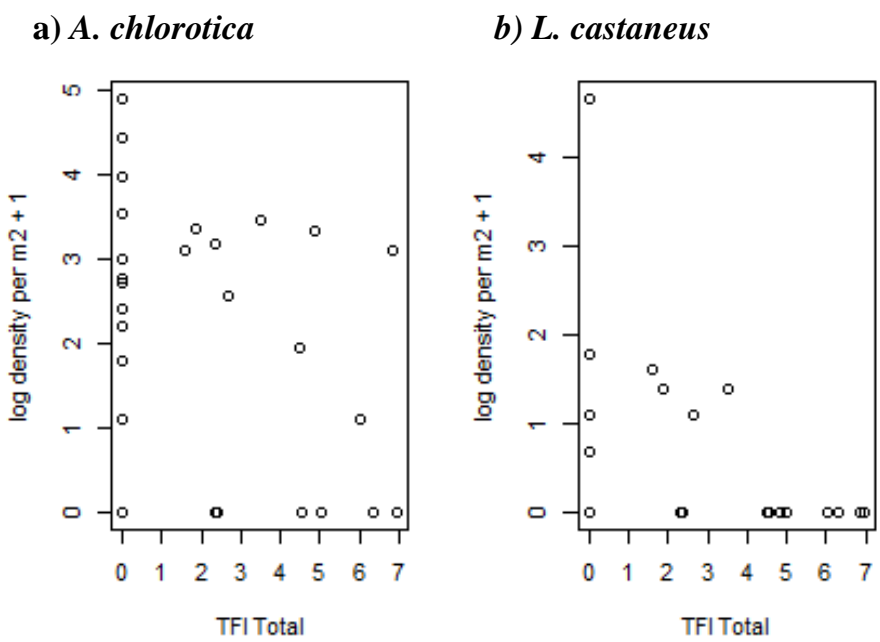

c) L. terrestris

\section{d) A. chlorotica}

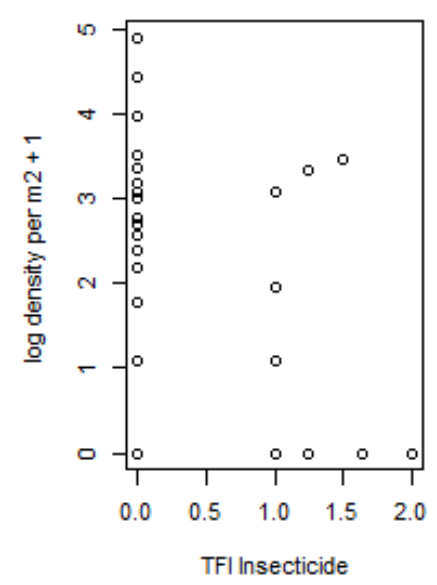

e) L. castaneus

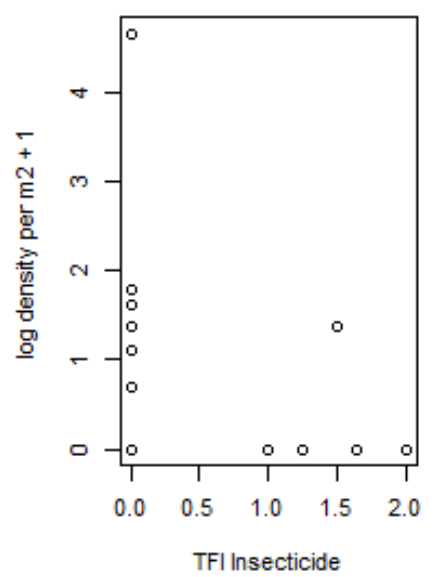

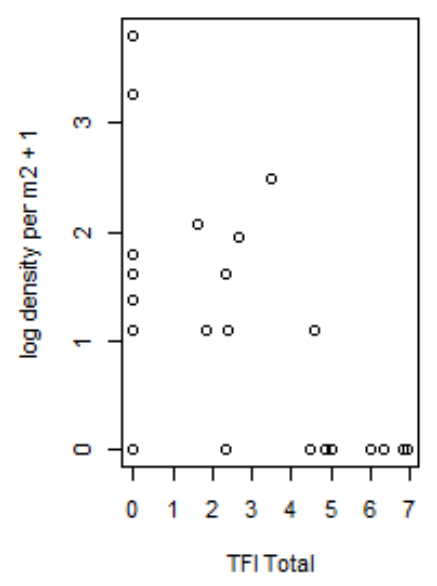

f) L. terrestris

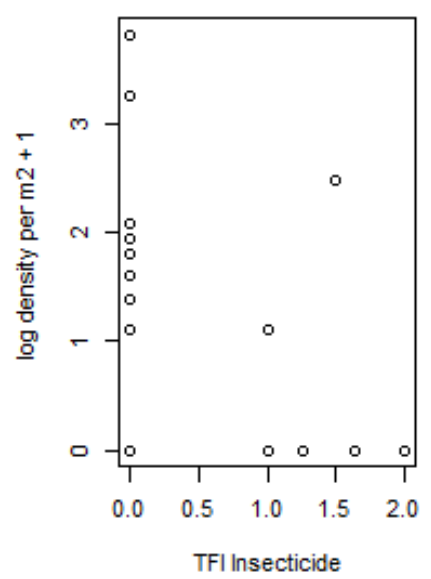


Fig. 2

A.

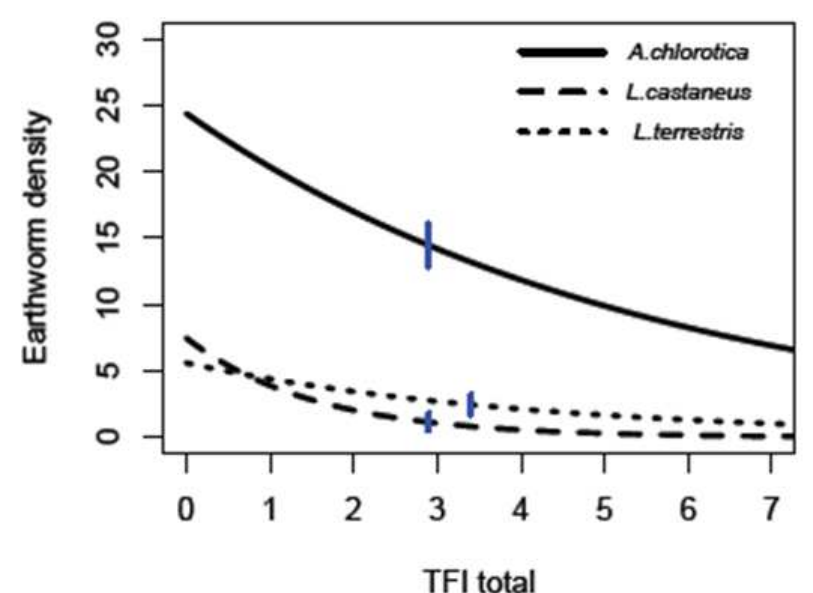

C.

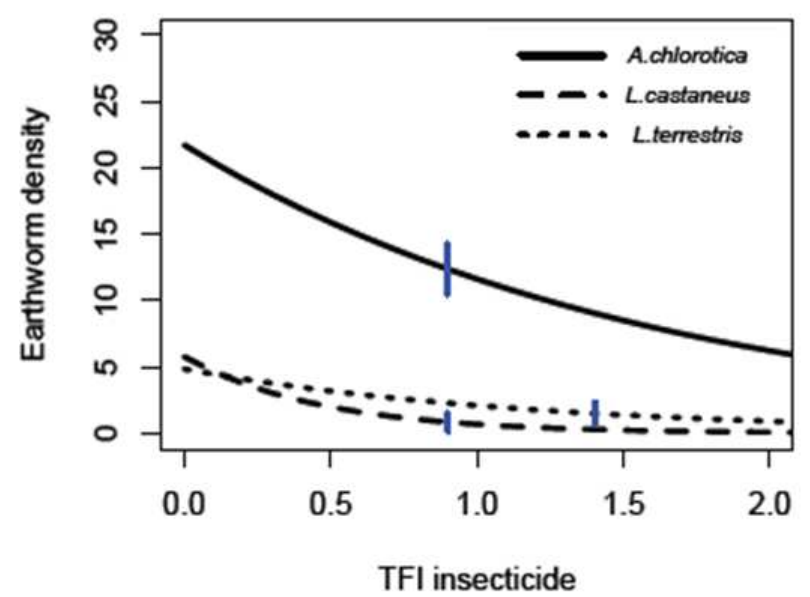

B.

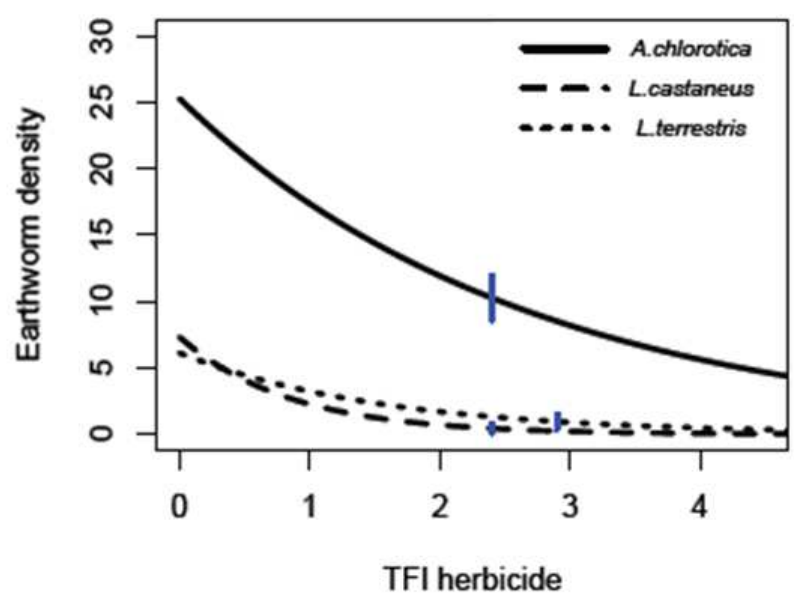

D.

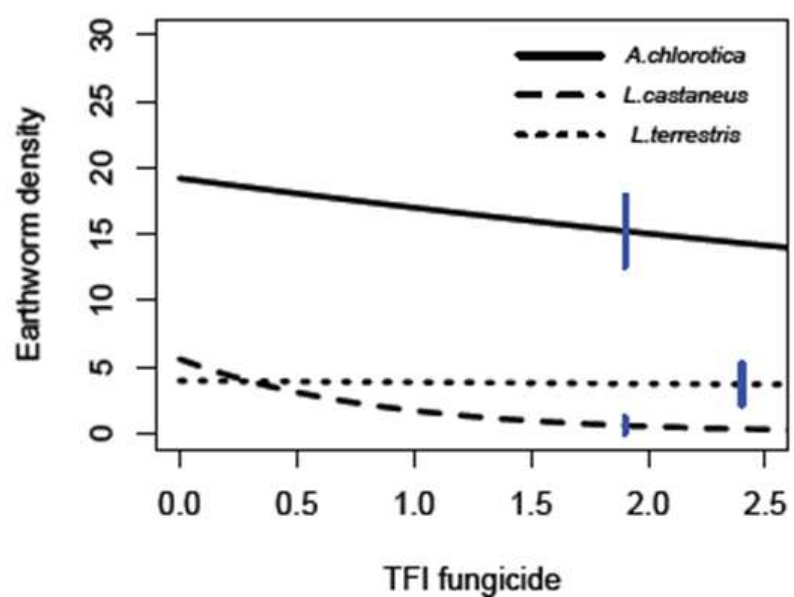


Fig. 1. Densities of the three earthworm species as a function of TFI Total (a, b, c) and of TFI insecticide (d, e, f) on the 30 site-years. TFI means Treatment Frequency Index. Earthworm densities were expressed as $\log \left(\right.$ density per $\left.\mathrm{m}^{2}+1\right)$.

Fig. 2. Poisson regressions of densities of the three earthworm species as a function of TFI

Total (A), TFI Herbicide (B), TFI Insecticide (C), and TFI Fungicide (D). TFI means Treatment Frequency Index. Vertical bars are 95\% confidence intervals. 
Appendix A: Site and soil characteristics of the twenty-two plots in Seine-et-Marne and the eight plots in Yvelines (same crop i.e. winter wheat).

\begin{tabular}{|c|c|c|c|c|c|c|c|c|c|c|c|c|}
\hline Plot name & Site & Year of soil sampling & GPS Coo & ordinates & Cropping system & Clay $\left(\mathrm{g} \mathrm{kg}^{-1}\right)$ & Silt $\left(\mathrm{g} \mathrm{kg}^{-1}\right)$ & Sand $\left(\mathrm{g} \mathrm{kg}^{-1}\right)$ & Organic matter $\left(\mathrm{g} \mathrm{kg}^{-1}\right)$ & $\mathrm{CaCO} 3\left(\mathrm{~g} \mathrm{~kg}^{-1}\right)$ & $\mathrm{C} / \mathrm{N}$ ratio & $\mathrm{pH}$ \\
\hline Org1 & Seine-et-Marne & 2012 & $\mathrm{~N} 48^{\circ} 79,909^{\prime}$ & E $3^{\circ} 13,267^{\prime}$ & Organic & 261.0 & 646.0 & 26.0 & 19.3 & 1.0 & 10.2 & 7.4 \\
\hline Org2 & Seine-et-Marne & 2012 & $\mathrm{~N} 48^{\circ} 66,961^{\prime}$ & E $3^{\circ} 17,820^{\prime}$ & Organic & 242.0 & 696.0 & 16.0 & 19.5 & 1.0 & 9.8 & 7.8 \\
\hline Org3 & Seine-et-Marne & 2012 & $\mathrm{~N} 48^{\circ} 67,099^{\prime}$ & E $3^{\circ} 17,904^{\prime}$ & Organic & 299.0 & 653.0 & 12.0 & 19.5 & 1.0 & 9.8 & 7.5 \\
\hline Org4 & Seine-et-Marne & 2012 & $\mathrm{~N} 48^{\circ} 68,602^{\prime}$ & E $2^{\circ} 78,570^{\prime}$ & Organic & 174.0 & 664.0 & 65.0 & 22.7 & 1.0 & 11.9 & 7.8 \\
\hline Org5 & Seine-et-Marne & 2012 & $\mathrm{~N} 48^{\circ} 43,157^{\prime}$ & E $3^{\circ} 32,136^{\prime}$ & Organic & 193.0 & 284.0 & 77.0 & 25.7 & 1.0 & 11.2 & 8.5 \\
\hline Org6 & Seine-et-Marne & 2012 & 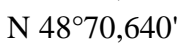 & E $2^{\circ} 67,897^{\prime}$ & Organic & 178.0 & 733.0 & 33.0 & 32.7 & 1.0 & 13.6 & 7.3 \\
\hline Org7 & Seine-et-Marne & 2012 & $\mathrm{~N} 48^{\circ} 76,876^{\prime}$ & E $3^{\circ} 15,272^{\prime}$ & Organic & 194.0 & 751.0 & 25.0 & 23.2 & 1.0 & 10.8 & 7.5 \\
\hline Org8 & Seine-et-Marne & 2012 & N 48 $76,566^{\prime}$ & E $3^{\circ} 14,826^{\prime}$ & Organic & 170.0 & 765.0 & 32.0 & 19.5 & 1.0 & 10.7 & 7.5 \\
\hline Org9 & Seine-et-Marne & 2012 & N 48 $64,506^{\prime}$ & E $3^{\circ} 04,909^{\prime}$ & Organic & 227.0 & 689.0 & 19.0 & 23.7 & 1.1 & 10.0 & 7.6 \\
\hline Org10 & Seine-et-Marne & 2012 & $\mathrm{~N} 48^{\circ} 29,850^{\prime}$ & E $2^{\circ} 87,968^{\prime}$ & Organic & 256.0 & 347.0 & 175.0 & 26.0 & 1.7 & 11.6 & 7.6 \\
\hline Org11 & Seine-et-Marne & 2012 & $\mathrm{~N} 48^{\circ} 84,641^{\prime}$ & E $3^{\circ} 10,906^{\prime}$ & Organic & 165.0 & 774.0 & 24.0 & 19.0 & 1.0 & 10.7 & 7.9 \\
\hline Org12 & Yvelines & 2005 & N $48^{\circ} 48^{\prime}$ & E $2^{\circ} 08^{\prime}$ & Organic & 174.0 & 605.0 & 222.0 & 16.7 & 0.9 & 9.8 & 7.2 \\
\hline Org13 & Yvelines & 2006 & $\mathrm{~N} 48^{\circ} 48^{\prime}$ & $\mathrm{E} 2^{\circ} 08^{\prime}$ & Organic & 174.0 & 605.0 & 222.0 & 16.7 & 0.9 & 9.8 & 7.2 \\
\hline Org14 & Yvelines & 2007 & $\mathrm{~N} 48^{\circ} 48^{\prime}$ & $\mathrm{E} 2^{\circ} 08^{\prime}$ & Organic & 174.0 & 605.0 & 222.0 & 16.7 & 0.9 & 9.8 & 7.2 \\
\hline Org15 & Yvelines & 2011 & $\mathrm{~N} 48^{\circ} 48^{\prime}$ & E $2^{\circ} 08^{\prime}$ & Organic & 174.0 & 605.0 & 222.0 & 17.1 & $<1$ & 10.1 & 7.4 \\
\hline Conv1 & Seine-et-Marne & 2012 & $\mathrm{~N} 48^{\circ} 61,808^{\prime}$ & E $2^{\circ} 96,832^{\prime}$ & Conventional & 204.0 & 704.0 & 28.0 & 18.1 & 1.0 & 9.9 & 7.9 \\
\hline Conv2 & Seine-et-Marne & 2012 & $\mathrm{~N} 49^{\circ} 03,467^{\prime}$ & E $2^{\circ} 84,154^{\prime}$ & Conventional & 213.0 & 723.0 & 12.0 & 18.2 & 5.5 & 9.9 & 8.1 \\
\hline Conv3 & Seine-et-Marne & 2012 & N 4906,166' & E $2^{\circ} 94,686^{\prime}$ & Conventional & 180.0 & 756.0 & 10.0 & 16.9 & 1.1 & 9.9 & 7.9 \\
\hline Conv4 & Seine-et-Marne & 2012 & $\mathrm{~N} 48^{\circ} 45,583^{\prime}$ & E $3^{\circ} 14,232^{\prime}$ & Conventional & 221.0 & 658.0 & 43.0 & 20.7 & 7.9 & 9.9 & 8.3 \\
\hline Conv5 & Seine-et-Marne & 2012 & $\mathrm{~N} 48^{\circ} 43,775^{\prime}$ & E $3^{\circ} 04,751^{\prime}$ & Conventional & 160.0 & 580.0 & 135.0 & 16.1 & 1.0 & 10.5 & 6.4 \\
\hline Conv6 & Seine-et-Marne & 2012 & $\mathrm{~N} 48^{\circ} 50,036^{\prime}$ & E $3^{\circ} 12,826^{\prime}$ & Conventional & 228.0 & 667.0 & 25.0 & 16.0 & 1.0 & 9.9 & 8.2 \\
\hline Conv7 & Seine-et-Marne & 2012 & $\mathrm{~N} 49^{\circ} 02,709^{\prime}$ & E $2^{\circ} 98,335^{\prime}$ & Conventional & 298.0 & 648.0 & 7.0 & 17.6 & 1.0 & 9.4 & 7.4 \\
\hline Conv8 & Seine-et-Marne & 2012 & N 48 $40,579^{\prime}$ & E $3^{\circ} 32,293^{\prime}$ & Conventional & 270.0 & 457.0 & 123.0 & 26.9 & 7.5 & 10.9 & 8.2 \\
\hline Conv9 & Seine-et-Marne & 2012 & N 48 $79,928^{\prime}$ & E $3^{\circ} 13,529^{\prime}$ & Conventional & 209.0 & 692.0 & 23.0 & 17.3 & 1.0 & 10.4 & 7.2 \\
\hline Conv10 & Seine-et-Marne & 2012 & $\mathrm{~N} 48^{\circ} 68,684^{\prime}$ & E $2^{\circ} 78,558^{\prime}$ & Conventional & 197.0 & 646.0 & 55.0 & 18.3 & 1.0 & 10.2 & 7.1 \\
\hline Conv11 & Seine-et-Marne & 2012 & N 48 $84,380^{\prime}$ & E $3^{\circ} 10,896^{\prime}$ & Conventional & 244.0 & 662.0 & 41.0 & 23.8 & 5.9 & 10.4 & 8.0 \\
\hline Conv12 & Yvelines & 2005 & $\mathrm{~N} 48^{\circ} 48^{\prime}$ & E $2^{\circ} 08^{\prime}$ & Conventional & 180.0 & 605.0 & 216.0 & 18.1 & 0.9 & 10.0 & 7.4 \\
\hline Conv13 & Yvelines & 2006 & $\mathrm{~N} 48^{\circ} 48^{\prime}$ & $\mathrm{E} 2^{\circ} 08^{\prime}$ & Conventional & 180.0 & 605.0 & 216.0 & 18.1 & 0.9 & 10.0 & 7.4 \\
\hline Conv14 & Yvelines & 2007 & $\mathrm{~N} 48^{\circ} 48^{\prime}$ & E $2^{\circ} 08^{\prime}$ & Conventional & 180.0 & 605.0 & 216.0 & 18.1 & 0.9 & 10.0 & 7.4 \\
\hline Conv15 & Yvelines & 2011 & N $48^{\circ} 48^{\prime}$ & E $2^{\circ} 08^{\prime}$ & Conventional & 180.0 & 605.0 & 216.0 & 17.8 & $<1$ & 10.5 & 7.3 \\
\hline
\end{tabular}


Appendix B: Active ingredients, DT50 and DT90 (mean Dissipation Time 50 and 90 in the field i.e. time for respectively $50 \%$ and $90 \%$ disappearance of the active ingredients applied at specific initial concentrations in the field) of the pesticides applied in the fifteen conventional fields i.e., eleven fields in Seine-et-Marne and four fields in Yvelines. DT50 and DT90 are mean DT50 and DT90 of all pesticides used in the field, respectively (PPDB, 2012).

\begin{tabular}{|c|c|c|c|c|}
\hline Plot name & Site & Active ingredients & DT50 (days) & DT90 (days) \\
\hline Conv1 & Seine-et-Marne & Sulcotrione, Nicosulfuron, Prosulfuron, Chlorantraniliprole & 12.4 & 58.4 \\
\hline Conv2 & Seine-et-Marne & Boscalid, Pyroxsulam, Isoproturon, Pendimethaline, Mesosulfuron-methyl-sodium, Iodosulfuron-methyl-sodium & 57.6 & 238.5 \\
\hline Conv3 & Seine-et-Marne & Phendimediphame, Ethofumesate, Triflusulfuron-methyl, Metamitrone, Lenacile, Clomazone, Flusilazole & 36.0 & 153.8 \\
\hline Conv4 & Seine-et-Marne & $\begin{array}{l}\text { Clodinafop-propargyl, Cloquintocet-mexyl, Bromoxynil, Ioxynil, Diflufenican, Ethofumesate, Phenmediphame, Metamitrone, } \\
\text { Cyproconazole, Azoxystrobine, Difenoconazole, Fenpropidine }\end{array}$ & 64.2 & 198.8 \\
\hline Conv5 & Seine-et-Marne & $\begin{array}{l}\text { Nicosulfuron, Prosulfuron, Mesomitrone, Lambda-cyhalothrine, S-metolachlore, Benoxacor, Chlortoluron, Betacyfluthrine, } \\
\text { Pyrimicarbe }\end{array}$ & 20.9 & 101.6 \\
\hline Conv6 & Seine-et-Marne & $\begin{array}{l}\text { Fluroxypyr, Clopyralid, CPA, 2,4,-D, Diflufenicanil, Chlortoluron, Prochloraze, Cyproconazole, Propiconazole, Chlorothalonil, } \\
\text { Epoxiconazole, Fenpropimorphe, Pyraclostrobine }\end{array}$ & 60.4 & 540.7 \\
\hline Conv7 & Seine-et-Marne & $\begin{array}{l}\text { Glyphosate, Ethofumesate, Phenmediphame, Lenacile, Clethodime, S-metolachlore, Propiconazole,Difenoconazole, Epoxiconazole, } \\
\text { Fenpropidine, Cypermethrine }\end{array}$ & 54.8 & 265.1 \\
\hline Conv8 & Seine-et-Marne & $\begin{array}{l}\text { Pendimethaline, Flurochloridone, Chlortoluron, Diflufenicanil, Ioxynil, Bromoxynil, Difenoconazole, Fenpropidine, Lambda- } \\
\text { cyhalothrine, Pyrimicarbe }\end{array}$ & 68.6 & 212.7 \\
\hline Conv9 & Seine-et-Marne & $\begin{array}{l}\text { Mesosulfuron-methyl-sodium, Iodosulfuron-methyl-sodium, Fluroxypyr, Metsulfuron-methyle, Tribenuron-methyle, Isoproturon, } \\
\text { Spiroxamine, Prothioconazole, Cyproconazole, Propiconazole, Chlorothalonil, Epoxiconazole, Fenpropimorphe, Prochloraze, }\end{array}$ & 52.8 & 376.6 \\
\hline Conv10 & Seine-et-Marne & $\begin{array}{l}\text { Tau-fluvalinate, Chortoluron, Bifenox, Ioxynil, Mecoprop-p, Pyroxsulam, Cloquintocet-mexyl, Florasulam, Propiconazole, } \\
\text { Cyproconazole, Chlorothalonil, Epoxiconazole, Fenpropidine, Prochloraze, Cypermethrine }\end{array}$ & 65.4 & 467.6 \\
\hline Conv11 & Seine-et-Marne & $\begin{array}{l}\text { Chlortoluron, Bifenox, Ioxynil, Mecoprop-p, Phenmediphame, Desmediphame, Ethofumesate, Metamitrone, Lenacile, Triflusulfuron- } \\
\text { methyl }\end{array}$ & 30.4 & 159.1 \\
\hline Conv12 & Yvelines & Pendimethaline, Aclonifen, Pyrimethanil, Chlorothalonil & 61.0 & 265.0 \\
\hline Conv13 & Yvelines & Pendimethaline, Aclonifen, Azoxystrobine & 117.0 & 427.1 \\
\hline Conv14 & Yvelines & Boscalid, Lambda-cyhalothrine & 71.5 & 238.5 \\
\hline Conv15 & Yvelines & Glyphosate, Diflufenicanil, Isoproturon & 116.7 & 51.0 \\
\hline
\end{tabular}


Appendix C: TFI values in the fifteen conventional plots i.e., eleven plots in Seine-et-Marne and four plots in Yvelines. TFI means Treatment Frequency Index.

\begin{tabular}{cccccc}
\hline Plot name & Site & TFI Total & TFI Herbicide & TFI Insecticide & TFI Fungicide \\
\hline Conv1 & Seine-et-Marne & 2.4 & 1.4 & 1.0 & 0.0 \\
Conv2 & Seine-et-Marne & 6.3 & 2.3 & 2.0 & 2.0 \\
Conv3 & Seine-et-Marne & 4.6 & 3.6 & 0.0 & 1.0 \\
Conv4 & Seine-et-Marne & 7.0 & 4.5 & 1.3 & 1.2 \\
Conv5 & Seine-et-Marne & 5.0 & 3.4 & 1.6 & 0.0 \\
Conv6 & Seine-et-Marne & 2.4 & 1.4 & 0.0 & 1.0 \\
Conv7 & Seine-et-Marne & 6.0 & 4.5 & 1.0 & 0.5 \\
Conv8 & Seine-et-Marne & 4.9 & 2.6 & 1.3 & 1.0 \\
Conv9 & Seine-et-Marne & 6.9 & 3.4 & 1.0 & 2.5 \\
Conv10 & Seine-et-Marne & 4.5 & 2.8 & 1.0 & 0.7 \\
Conv11 & Seine-et-Marne & 2.4 & 2.4 & 0.0 & 0.0 \\
Conv12 & Yvelines & 2.7 & 1.7 & 0.0 & 1.0 \\
Conv13 & Yvelines & 1.9 & 1.7 & 0.0 & 0.2 \\
Conv14 & Yvelines & 3.5 & 0.0 & 1.5 & 2.0 \\
Conv15 & Yvelines & 1.6 & 1.6 & 0.0 & 0.0 \\
\hline
\end{tabular}

